\title{
LOW-MOLECULAR COMPONENTS OF COLOSTRUM AS A REGULATOR OF THE ORGANISM REDOX-SYSTEM AND BIOLOGICAL ANTIDOTE
}

\author{
Ievgen Ivanov \\ Department of Molecular Biology and Biotechnology \\ E-mail: ivanovevg321@gmail.com \\ Valentyn Kozheshkurt ${ }^{1}$ \\ E-mail:v.kozheshkurt@karazin.ua \\ Anatoly Bozhkov ${ }^{2}$ \\ E-mail:bozhkov@univer.kharkov.ua \\ Anatolii Goltvjansky² \\ E-mail:profkom@karazin.ua \\ Victor Katrich \\ E-mail:vkatrich@karazin.ua \\ Vadim Sidorov ${ }^{2}$ \\ E-mail:visidorov@univer.kharkov.ua \\ Taras Gromovoy \\ Laboratory of Mass Spectrometry of Surface of Nanosystems \\ Chuiko Institute of Surface Chemistry \\ 17 Henerala Naumova str., Kyiv, Ukraine, 03164 \\ E-mail:grota@ukr.net \\ ${ }^{2}$ Research Institute of Biology \\ ${ }^{3} V$. N. Karazin Kharkiv National University \\ 4 Svobody sq., Kharkiv, Ukraine, 61022
}

${ }^{1}$ Department of Physical and Biomedical Electronics and Complex Information Technologies ${ }^{3}$

\footnotetext{
Abstract

The protein composition in the diapason of molecular masses from 4800 to $9500 \mathrm{Da}$ has been studied in colostrum, taken from different cows, and manifested the expressed biological activity. For this aim, an influence of low-molecular components of colostrum on some physiological parameters (change of body mass and temperature) at intoxication of animals (Wistar rats) by blue stone has been studied. An influence of colostrum low-molecular components on parameters of the organism redox-system (content of hyperperoxides of lipids and activity of glutathione peroxidase) in the blood serum of animals has been studied. For determining integral characteristics of colostrum components, electric conductivity of skim colostrum and one of colostrum with low-molecular proteins (less than $10000 \mathrm{Da}$ ), taken from different cows, were used. The aim of this work is to study interconnections of an influence of colostrum low-molecular proteins on models of organism intoxication by cooper ions.

It is demonstrated, that the colostrum composition includes 25-35 different proteins with a molecular mass from 4800 to $9500 \mathrm{Da}$. The number and ratio between protein fractions depend on individual physiological-biochemical characteristics of producers. It has been revealed, that there is no direct dependence between the protein content in a measuring cell $(2 \mathrm{mg} /$ $\mathrm{ml}, 4 \mathrm{mg} / \mathrm{ml}$ and $10 \mathrm{mg} / \mathrm{ml}$ ) with skim colostrum and electric conductivity change, and this dependence is different for skim colostrum, taken from different cows. Individual differences are manifested both at electric conductivity change and by the content of colostrum low-molecular proteins in a measuring cell. It is demonstrated, that colostrum low-molecular components can eliminate the toxic effect of blue stone on the organism, which mechanisms are connected with a balance shift in the sys-
} 
tem "prooxidants↔antioxidants" towards antioxidants. The electric conductivity of colostrum components may be used as an express-method for evaluating biologically active substances of colostrum.

Keywords: colostrum, biologically active compounds, low-molecular proteins, electric conductivity, glutathione peroxidase, hydroeroxides of lipids.

DOI: $10.21303 / 2504-5695.2021 .001738$

\section{Introduction}

It is known, that metabolism programming, determining not only peculiarities of ontogenesis, but also a risk of a series of pathologies, takes place in neonatal and early postnatal ontogenesis $[1,2]$. It was demonstrated, that excessive nutrition in the early postnatal period formed specific metabolic patterns, preserved during the whole ontogenesis and correlated with lifespan [3]. Today active studies of an influence of animals' feeding peculiarities at early stages of ontogenesis on the mechanism of metabolic and immunologic programming and formation of epigenetic regulation processed are conducting [3].

Studies of colostrum and its influence on the biological systems functioning are of more interest in this case. It is explained by the fact that the placenta structure in ruminants prevents immunoglobulins transmission to a fetus, and newborn calves are deprived of so-called passive immunity $[4,5]$. In the process of evolution, the transmission system of the molecules complex, supporting the immunity and metabolism programming by colostrum, formed.

Colostrum is a unique liquid, forming in mammary glands during only several days after delivery [6,7] and is rich in immunoglobulins and other growth factors [8] with the extremely wide spectrum of biologically active substances [9]. It is demonstrated, that immunoglobulins transmission to newborns by colostrums is called colostrums immunity [5], and it is the most important survival factor of newborns in the early postnatal period [10]. Together with immunity, colostrum components provide metabolism formation and its epigenetic component. In this connection studies of the colostrum component are of great interest, because it favors peculiarities of postnatal development, protection from infectious agents and other negative environmental factors.

One of most spread environmental factors, negatively influencing the organism, is ions of heavy metals, especially, copper ones [11]. It is known, that cooper ions, penetrating the organism, can cause oxidative stress, and at the chronic influence - result in hepatic fibrosis [12]. In this connection it is interesting to study the influence of colostrum components on parameters of the organism redox-system at intoxication by blue stone.

Many works are devoted to studying the colostrum composition, and it is demonstrated, that it is very rich in proteins, and their composition depends on a "producer", contains relatively small amount of lipids [13], it is rich in microelements [14]. But the most important characteristic of colostrum may be considered its instability and composition dynamics. In this connection it is necessary to search and to develop methods, allowing to evaluate the dynamics of changing colostrum integral characteristics.

Such biophysical method as electric conductivity measuring may be used as integral parameters of multicomponent dynamic biological mixtures. This approach allows to evaluate the total number of charged ions and other molecules in colostrum [15]. The most biological activity in metabolism regulation mechanisms is inherent to peptides and low-molecular proteins. That is why it may be expected, that an index of colostrum components electric conductivity allows to evaluate the quality and potential biological activity of complex, multicomponent, dynamic mixtures fast. But "a contribution" of proteins, especially ones with different molecular masses in the electric conductivity index has not been studied.

It may be concluded, that colostrum in a unique biological product that can provide metabolism regulation, including at organism intoxication by heavy metal ions. But colostrum is not stable as a multicomponent mixture, and its composition depends on many parameters. In this connection, it is necessary to search for fast and effective methods of colostrum quality 
evaluation. The aim of this was to study an interconnection between the content of low-molecular proteins with the electric conductivity and biological activity of colostrum on the model of organism intoxication by cooper ions. At that such organism redox-system parameters as content of hydroperoxides of lipids and glutathione peroxidase activity in the blood serum at animals' intoxication by cooper ions were determined.

\section{Materials and methods}

Colostrum was obtained at the Farm economy "Alfa" (Ukraine) from cows on the Ukrainian milky-pitted breed, second milk yield after calving. Skimming was conducted at colostrum centrifuging at $3000 \mathrm{~g}$ during $20 \mathrm{~min}$ at room temperature. After eliminating lipids, all proteins with a molecular mass more than $10000 \mathrm{Da}$ were removed from skim colostrum by membrane filtration. Electric conductivity was measured in the obtained fraction with low-molecular proteins by a vector analyzer ZNB 40 "Rohde \& Schwarz" (Austria). Specific electric conductivity was measured in the frequency diapason as $100 \mathrm{kHz}-10 \mathrm{MHz}$ with interval $50 \mathrm{kHz}$. After that samples were dried in a rotation apparatus. Intoxication was conducted by threefold administration of blue stone to the experimental animals with interval 48 hours that was 5 days after the beginning of the experiment, in dose $0.1 \mathrm{mg} / 100 \mathrm{~g}$ of the body mass. The obtained samples of low-molecular proteins were dissolved in a physiological solution and administered to the experimental animals per os in dose $0.1 \mathrm{mg} / 100 \mathrm{~g}$ of the body mass. After 24 hours the animals were experimented. The blood serum was taken, and the content of hydroperoxides of lipids was determined in it by method [16] and glutathione peroxidase by [17]. The content of low-molecular proteins was determined on a mass-spectrometer Autoflex II LRF 20 "Bruker Daltonics" (Germany), equipped by an impulse nitrogen laser ( $\lambda=337 \mathrm{~nm}$, impulse duration $3 \mathrm{~ns})$. The obtained results were statistically processed by Mann-Whitney method using the program software Statistica 8.0 (StatSoft Inc., USA). Differences between the control and experimental groups were accepted reliable at $p<0.05$, comparing with a control variant.

\section{Results}

The composition of proteins with a molecular mass less than $10 \mathrm{kDa}$ in different producers. The study of colostrum proteins with a molecular mass from $4800 \mathrm{Da}$ to $9500 \mathrm{Da}$ demonstrated that 27 fractions were revealed in the cow Aurora (Fig. 1, a). The content of these proteins was different, the most amount was of proteins with a molecular mass of 5500-6000 Da and 65007000 Da (Fig. 1, a).

The content of colostrum proteins in this diapason of molecular masses in the cow Barinya was different. Thus, 31 fractions were identified by the method of mass-spectroscopy (Fig. 1, b). If analyze coincidences of colostrum protein fractions, taken from the different cows, it may be concluded, that only 5 fractions were equal in the two cows (Fig. 1, c).

The obtained results indicate that colostrum as most biological substances has a unique composition that is depends on genetic and epigenetic characteristics of a producer. These peculiarities must be taken into account at receiving and further standardization of multicomponent biological mixtures.

The electric conductivity of components of colostrum, taken from different producers. It is known, that lipids manifest dielectric properties [18], and their elimination is accompanied by an electric conductivity increase as it was demonstrated above [15]. Lipids elimination from colostrum demonstrated that $92 \%$ of proteins, $7.69 \%$ of carbohydrates and $0.31 \%$ of vitamins and other substances, including ions, took place in skim milk counting for solid residue (Fig. 2). It may be stated, that skim colostrum is a concentrated solution of proteins with different molecular masses.

The determination of the dependence of specific electric conductivity on protein concentration, introduced in a measuring cell, demonstrated that at introducing 2 or $4 \mathrm{mg} / \mathrm{ml}$ the electric conductivity of skim colostrum, taken from the cow Aurora was the same. At introducing $10 \mathrm{mg} / \mathrm{ml}$ in the cell, the electric conductivity increased by $2 \%$ (Fig. 3, a). If skim milk 
was taken from Barinya, the concentration increase didn't result in an electric conductivity increase, the same is for Aurora's colostrum (Fig. 3, b). These data testify to the absence of a direct mutual connection between protein content and electric conductivity.
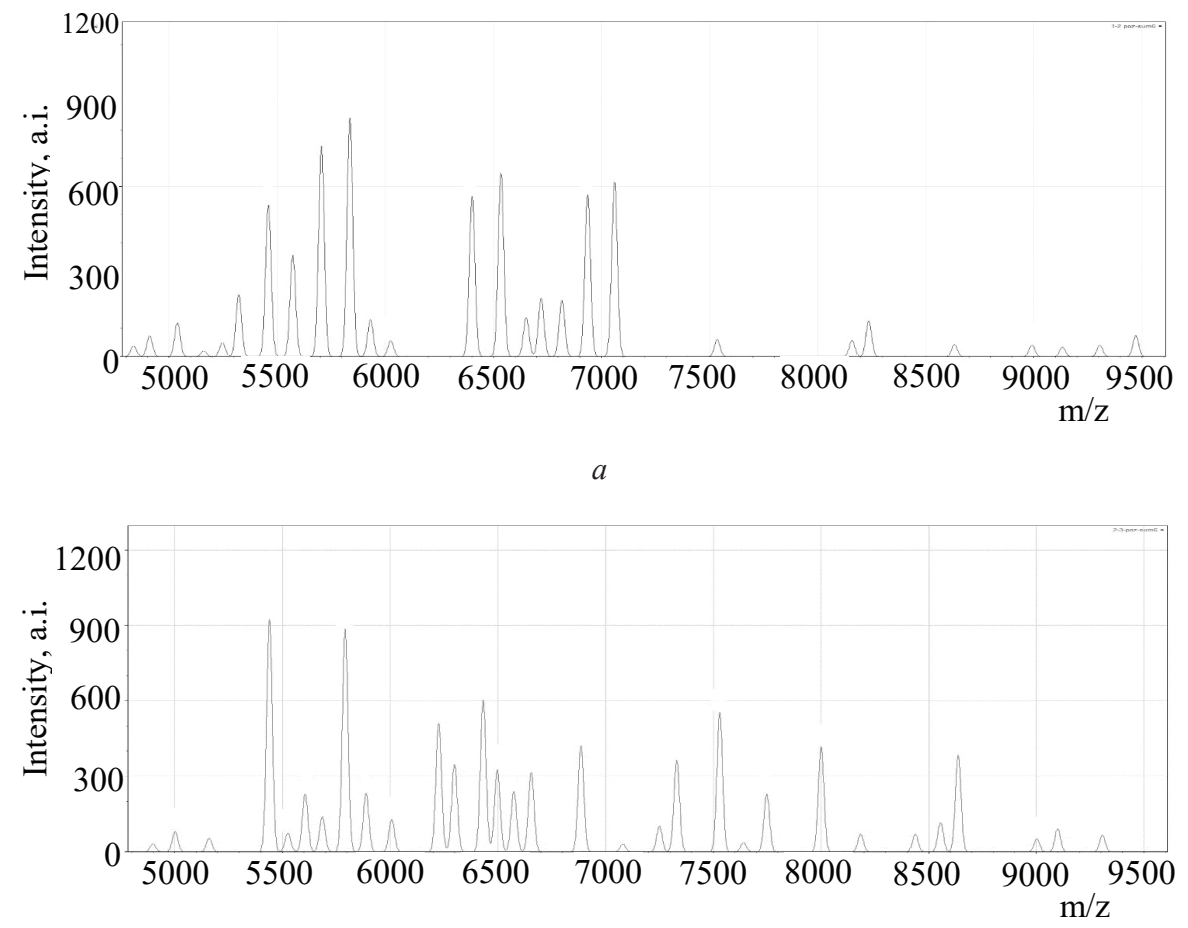

$b$

\begin{tabular}{|c|c|c|c|c|c|c|c|c|}
\hline $\begin{array}{l}\text { Values diapason } \\
\mathrm{m} / \mathrm{z}, \mathrm{Da}\end{array}$ & Cow name & \multicolumn{7}{|c|}{$\begin{array}{l}\text { Protein groups by the ratio between mass and } \\
\text { charge } \mathrm{m} / \mathrm{z} \text {, Da in the given diapasons }\end{array}$} \\
\hline \multirow{2}{*}{$4800-5300$} & Aurora & 4835 & 4909 & & & 5037 & 5159 & 5245 \\
\hline & Barinya & & & 4897 & 5000 & & 5158 & \\
\hline \multirow{2}{*}{$5300-5700$} & Aurora & 5321 & & 5458 & & 5571 & & \\
\hline & Barinya & & 5438 & & 5524 & & 5603 & 5683 \\
\hline \multirow{2}{*}{$5700-6100$} & Aurora & 5703 & & 5835 & & 5930 & & 6024 \\
\hline & Barinya & & 5790 & & 5886 & & 6005 & \\
\hline \multirow{2}{*}{$6100-6600$} & Aurora & & & 6400 & & & 6534 & \\
\hline & Barinya & 6224 & 6297 & & 6430 & 6496 & & 6573 \\
\hline \multirow{2}{*}{$6600-7100$} & Aurora & 6650 & 6720 & 6816 & & 6934 & 7059 & \\
\hline & Barinya & 6653 & & & 6884 & & & 7078 \\
\hline \multirow{2}{*}{$7100-8000$} & Aurora & & & 7534 & & & & \\
\hline & Barinya & 7248 & 7329 & 7528 & 7639 & 7747 & 7999 & \\
\hline \multirow{2}{*}{$8000-9000$} & Aurora & 8157 & & 8235 & & & 8635 & 8990 \\
\hline & Barinya & & 8183 & & 8436 & 8553 & 8631 & \\
\hline \multirow{2}{*}{$9000-9500$} & Aurora & & & 9131 & 9304 & 9470 & & \\
\hline & Barinya & 9001 & 9097 & & 9305 & & & \\
\hline
\end{tabular}

$c$

Fig. 1. Composition of proteins of colostrum low-molecular fractions by the data of massspectrometry: $a$-colostrum, taken from the cow Aurora; $b$ - colostrum, taken from the cow Barinya. Typical spectrums of proteins are presented; $c$ - ratio between the molecular mass and the protein charge in Aurora and Barinya, the proteins, coinciding by the ratio between the molecular mass and the protein charge in Aurora and Barinya, are marked dark 


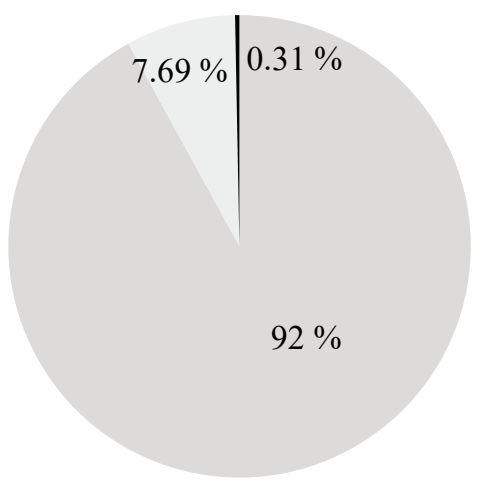

Fig. 2. Protein content $(\quad$ ), sugars ( $)$ and other non-identified components $(\square)$ in skim colostrum counting for solid residue

High-molecular proteins (more $10 \mathrm{kDa}$ ) that were the most part of proteins were eliminated from skim colostrum. In this case there was observed the linear dependence between the electric conductivity increase and the content of low-molecular proteins in a cell, if colostrum was taken from Barinya (Fig. 3, d). If colostrum was taken from Aurora, the non-linear increase was observed (Fig. $3, \boldsymbol{b})$.

So, the electric conductivity of both skim colostrum and colostrum low-molecular proteins demonstrate an individual character of change, because these characteristics were different for colostrum of the different cows. These results may testify to the fact that ratios of charged/neutral molecules are different in the different cows, and electric conductivity may serve an integral parameter of multicomponent mixtures. Electric conductivity depends not only and possibly not so much on molecules number, but is determined by the number of charged molecules and ions and ratio between molecules sizes in a mixture (low-molecular and high-molecular proteins).

Taking into account these expressed individual characteristics of colostrum, we offer to conduct further studies at the group level that is to combine colostrum of at least 5 producers at obtaining biologically active substances before processing for eliminating individual differences. At the next stage of the work colostrum, taken from 5 cows of the same breed, was combined, skimmed, and obtained low-molecular components were used as biologically active complexes.

The influence of colostrum low-molecular components on some parameters of organism redox-systems after intoxication by blue stone. Intoxication of the experimented animals was accompanied by their body mass loss during first 2-3 days (Fig. 4, a). In further their mass remained stable up to 10-12 days, then they restored the body mass growth again, and didn't differ from the control group after 16 days of the experiment (Fig. 4, a).

The body mass loss and the growth stop were observed at the reliable body temperature decrease (Fig. $4, \boldsymbol{b}$ ). Thus, if the body temperature of the intact control group remained stable during the experiment as $37.5^{\circ} \mathrm{C}$, in the animals after intoxication it was by $1{ }^{\circ} \mathrm{C}$ lower than the control (Fig. 4, b).

If the animals received colostrum low-molecular components (CLC) per os and blue stone was administered to them, their body mass growth, comparing with the control, stopped. Just after 6 days after the beginning of the experiment their growth had recovered, and by 20 days then didn't differ from the control group and even a bit exceeded it (Fig. 4, a). At that the body temperature of the animals, received CLC at intoxication, didn't differ from the control animals' one (Fig. 4, b).

Consequently, CLC can eliminate the negative inhibiting effect of blue stone on metabolism and may be considered as a potential antidote. Mechanisms of this effect may be extremely diverse. 


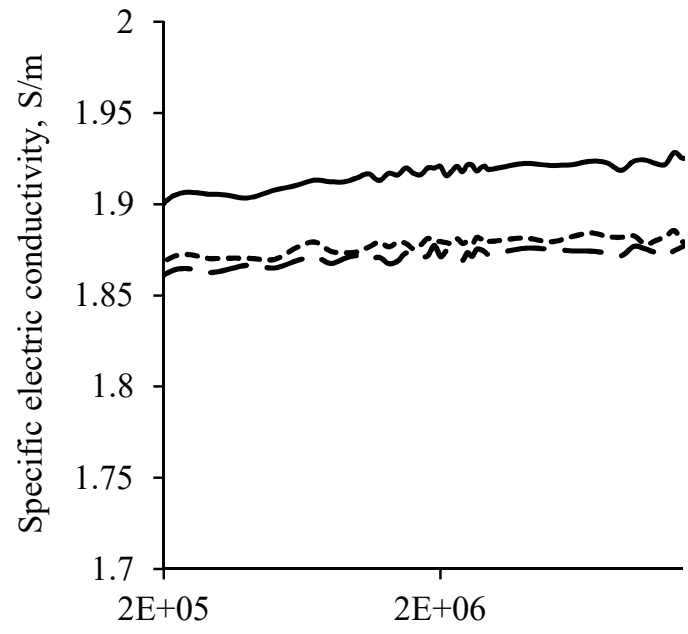

Frequency, $\mathrm{Hz}$

$a$

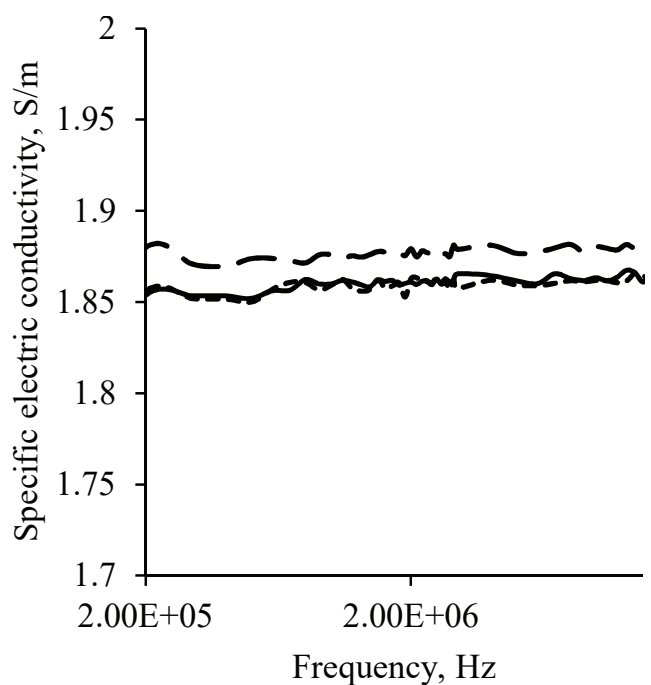

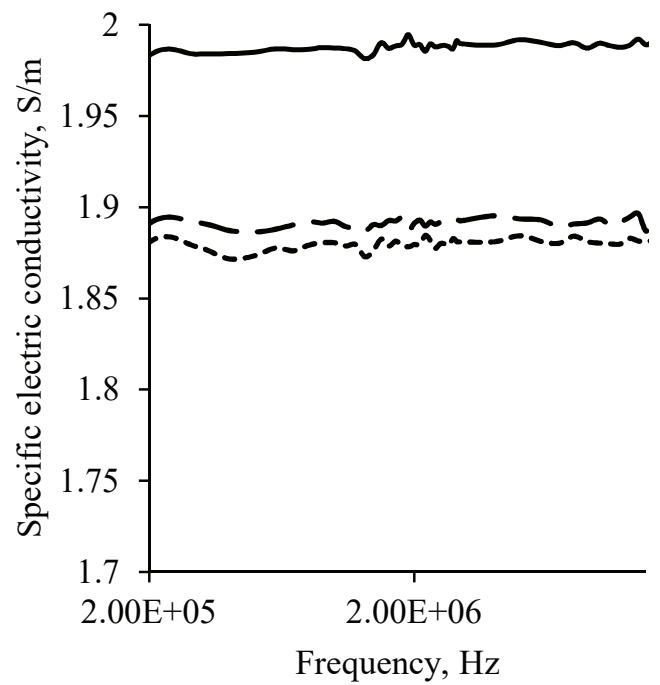

$b$

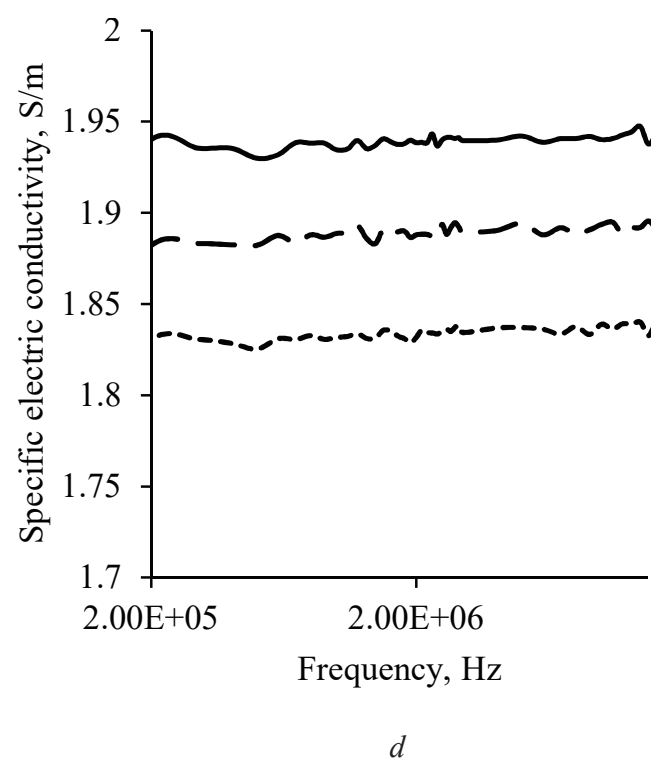

Fig. 3. Electric conductivity of colostrum components at introducing in a measuring cell $2 \mathrm{mg} / 1(----), 4 \mathrm{mg} / 1(--)$ and $10 \mathrm{mg} / 1$ ( - ) of proteins: $a$ - electric conductivity of skim colostrum, taken from Aurora; $b$ - electric conductivity of low-molecular components of colostrum, taken from Aurora; c - electric conductivity of skim colostrum, taken from Barinya;

$d$ - electric conductivity of low-molecular components of colostrum, taken from Barinya

It is known, that cooper ions may manifest the prooxidant effect, connected with increasing products of free radical reactions [19]. The next series of experiments demonstrated that after 24 hours after the last administration of blue stone to the animals, the content of hydroperoxides in the blood serum increased by $75 \%$, comparing with the control (Fig. 5, a). Such increase of products of free radical reactions took place at inhibition (by $36 \%$ ) of one of "central" antioxidant enzymes - glutathione peroxidase (Fig. 5, b).

If at intoxication the animals received CLC threefold in dose $0.1 \mathrm{mg} / 100 \mathrm{~g}$ of the body mass, the content of lipid hydroperoxides in the blood serum didn't differ from the control. The activity of glutathione peroxidase in this case even exceeded such of the intact control elements by $30 \%$ (Fig. $5, \boldsymbol{b})$. 


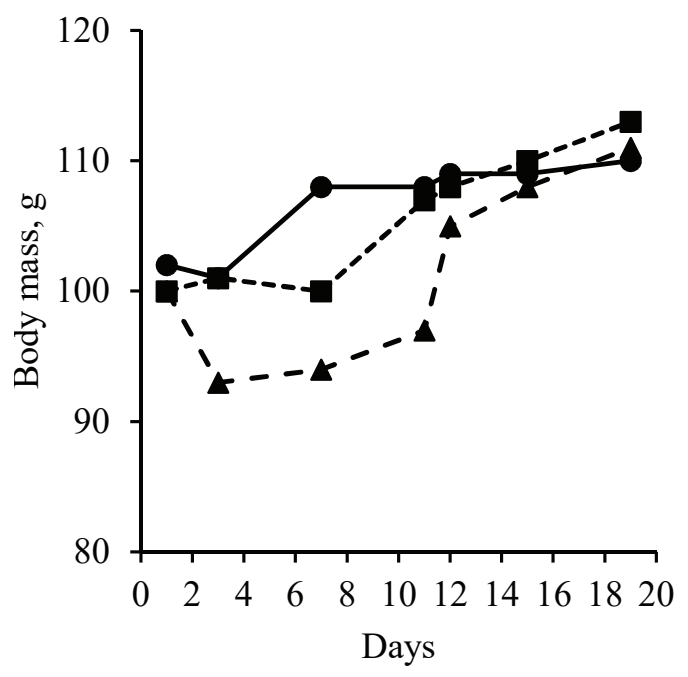

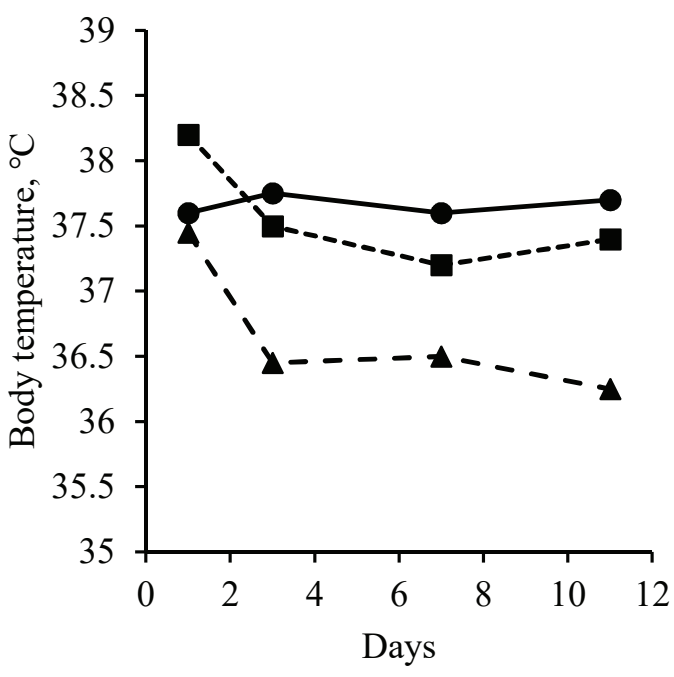

$b$

Fig. 4. Change of physiological parameters in the control group of animals $(\boldsymbol{\Delta})$, in the animals after blue stone intake ( $\mathbf{a})$ and in the ones with toxicosis after taking low-molecular components of colostrum in dose $0.1 \mathrm{mg} / 100 \mathrm{~g}$ of the body mass ( $\bullet$ : $a$ - body mass; $b$ - body temperature. The average values for 5 animals in each group are presented

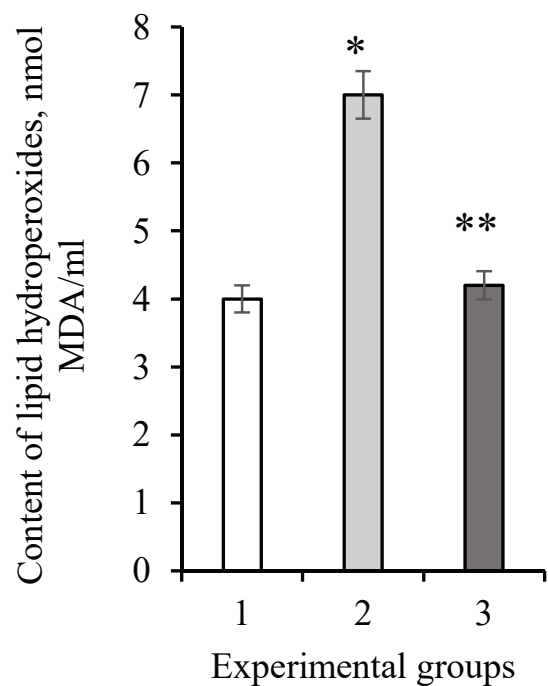

$a$

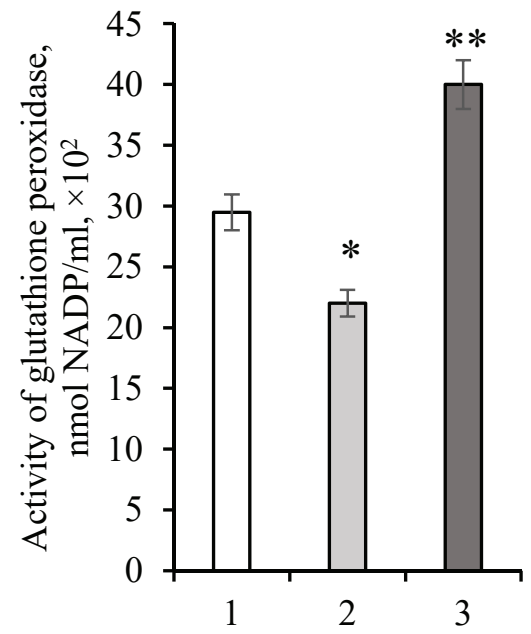

Experimental groups

$b$

Fig. 5. Change of redox-system parameters of the experimental animals (1), animals with toxicosis (2) and animals, administered with colostrum low-molecular components in dose $0.1 \mathrm{mg} / 100 \mathrm{~g}$ (3): $a$-content of hydroperoxides of lipids in the blood serum; $b$-activity of glutathione peroxidase in the blood serum. The average values of 5 animals in each group are presented

So, elimination mechanisms of the toxic effect of cooper ions by colostrum low-molecular components are realized through regulation of the organism redox-system. Based on CLC, medical preparations, able to eliminate the toxic effect of heavy metal ions and possibly of other toxicants, may be developed, and the electric conductivity of colostrum substances may be used as standardization methods.

The "individual" composition character of proteins with a low molecular mass (less than $10000 \mathrm{Da}$ ) is conditioned by several causes. Among them are genetic characteristics, physiological-biochemical status as a result of "interrelations and mutual influences" between the genome 
and living conditions of the animals, age, number of calvings and also time and number of milk yields after calving [20]. At the same time the content of colostrum and proteins is influenced by season and a series of other factors [21]. Storage time of colostrum cannot be also excluded, because its composition includes diverse enzymes with protease activity. In this connection it may be stated, that by its composition colostrum is a unique, high-dynamic substance with the brightly expressed biological activity. These peculiarities complicate receiving of biological substances from colostrum. It is connected with a fact that it is impossible to get substances with equal standard characteristics, and control methods need great time and material costs.

These questions may be solved by combining colostrum, taken from five and more animals for eliminating brightly expressed individual characteristics. Electric conductivity evaluation may be used as a control method for both colostrum and components, obtained from it. Electric conductivity depends not only on ions content, but also on number of lipids and low-molecular proteins as it is demonstrated in this work. That is why this method allows to get data about the ratio of different molecules in the colostrum composition that is an important characteristic of biological activity of substances. It is testified by the obtained data on CLC influence on the organism protection from blue stone effects.

\section{Conclusions}

The colostrum composition includes 25-35 proteins with molecular masses from 4800 to $9500 \mathrm{Da}$. Number, content and ratio between fractions depend on animals.

A direct dependence between the electric conductivity of skim colostrum, low-molecular components of colostrum and concentrations in a measuring cell is absent. This dependence was different for colostrum from different animals and reflects their individual physiological-biochemical peculiarities.

Colostrum low-molecular components can eliminate the toxic effect of blue stone on the organism, which mechanisms are connected with regulation of the prooxidant-antioxidant system that is a balance shift towards antioxidants.

\section{References}

[1] Koletzko, B., Chourdakis, M., Grote, V., Hellmuth, C., Prell, C., Rzehak, P. et. al. (2014). Regulation of Early Human Growth: Impact on Long-Term Health. Annals of Nutrition and Metabolism, 65 (2-3), 101-109. doi: https://doi.org/10.1159/000365873

[2] Brands, B., Demmelmair, H., Koletzko, B. (2014). How growth due to infant nutrition influences obesity and later disease risk. Acta Paediatrica, 103 (6), 578-585. doi: https://doi.org/10.1111/apa.12593

[3] Bozhkov, A. I., Nikitchenko, Yu. V., Al-Bahadly Ali, M. M. (2016). Overeating in Early Postnatal Ontogenesis Forms Metabolic Memory and Reduces Lifespan. Journal of Gerontology \& Geriatric Research, 5 (3). doi: https://oi.org/10.4172/2167-7182.1000309

[4] Baintner, K. (2007). Transmission of antibodies from mother to young: Evolutionary strategies in a proteolytic environment. Veterinary Immunology and Immunopathology, 117 (3-4), 153-161. doi: https://doi.org/10.1016/j.vetimm.2007.03.001

[5] Callahan, G. N., Yates, R. M. (2014). Basic veterinary immunology. University Press of Colorado, 337.

[6] Li, M., Li, Q., Kang, S., Cao, X., Zheng, Y., Wu, J. et. al. (2020). Characterization and comparison of lipids in bovine colostrum and mature milk based on UHPLC-QTOF-MS lipidomics. Food Research International, 136, 109490. doi: https://doi.org/ 10.1016/j.foodres.2020.109490

[7] McGrath, B. A., Fox, P. F., McSweeney, P. L. H., Kelly, A. L. (2016). Composition and properties of bovine colostrum: a review. Dairy Science \& Technology, 96 (2), 133-158. doi: https://oi.org/10.1007/s13594-015-0258-x

[8] Borad, S. G., Singh, A. K. (2018). Colostrum immunoglobulins: Processing, preservation and application aspects. International Dairy Journal, 85, 201-210. doi: https://doi.org/10.1016/j.idairyj.2018.05.016

[9] Hyrslova, I., Krausova, G., Michlova, T., Kana, A., Curda, L. (2020). Fermentation Ability of Bovine Colostrum by Different Probiotic Strains. Fermentation, 6 (3), 93. doi: https://doi.org/10.3390/fermentation6030093

[10] Pithua, P., Aly, S. S. (2013). A cohort study of the association between serum immunoglobulin G concentration and preweaning health, growth, and survival in Holstein calves. International Journal of Applied Research in Veterinary Medicine, 11 (1), 77-84.

[11] Bozhkov, A. I., Nikitchenko, Y. V., Lebid, K. M., Ivanov, E. G., Kurguzova, N. I., Gayevoy, S. S., Al Begai M. A. Y. (2017). Low molecular weight components from various sources eliminate oxidative stress and restore physiological characteristic of animals at early stages of $\mathrm{Cu}$ - induced liver fibrosis development. Translational Biomedicine, 8 (2). doi: https://doi.org/ 10.21767/2172-0479.1000107 
[12] Bozhkov, A. I., Nikitchenko, Y. V., Klimova, E. M., Linkevych, O. S., Lebid, K. M., Al-Bahadli, A. M. M., Alsardia, M. M. A. (2017). Young and old rats have different strategies of metabolic adaptation to $\mathrm{Cu}$-induced liver fibrosis. Advances in Gerontology, 7 (1), 41-50. doi: https://doi.org/10.1134/s2079057017010040

[13] Elfstrand, L., Lindmark-Månsson, H., Paulsson, M., Nyberg, L., Åkesson, B. (2002). Immunoglobulins, growth factors and growth hormone in bovine colostrum and the effects of processing. International Dairy Journal, 12 (11), 879-887. doi: https:// doi.org/10.1016/s0958-6946(02)00089-4

[14] Miciński, J., Miciński, J., Pogorzelska, J., Shaikamal, G. I., Sobczuk-Szul, M., Beisenov, A. et. al. (2016). Basic and mineral composition of colostrum from cows in different ages and calving period. Journal of Elementology, 22 (1), 259-269. doi: https://doi.org/10.5601/jelem.2016.21.2.1159

[15] Kozheshkurt, V., Ivanov, I., Antonenko, Y., Katrich, V., Bozhkov, A., Gromovoy, T. (2021). Devising an express method for estimating the quality of colostrum and its components based on electrical electric conductivity. Eastern-European Journal of Enterprise Technologies, 1 (11 (109)), 69-77. doi: https://doi.org/10.15587/1729-4061.2021.225007

[16] Asakawa, T., Matsushita, S. (1980). Coloring conditions of thiobarbituric acid test for detecting lipid hydroperoxides. Lipids, 15 (3), 137-140. doi: https://doi.org/10.1007/bf02540959

[17] Paglia, D. E., Valentine, W. N. (1967). Studies on the quantitative and qualitative characterization of erythrocyte glutathione peroxidase. The Journal of laboratory and clinical medicine, 70 (1), 158-169.

[18] Gramse, G., Dols-Perez, A., Edwards, M. A., Fumagalli, L., Gomila, G. (2013). Nanoscale Measurement of the Dielectric Constant of Supported Lipid Bilayers in Aqueous Solutions with Electrostatic Force Microscopy. Biophysical Journal, 104 (6), 1257-1262. doi: https://doi.org/10.1016/j.bpj.2013.02.011

[19] Bozhkov, A. I., Linkevych, O. S., Ivanov, E. G., Klimova, O. M., Al Begai, M. A. Y. (2016). Low molecular weight components of colostrum regulate the activity of cellular component of the immune system in animals with $\mathrm{Cu}$-induced liver fibrosis. International Journal of Current Research, 8 (12), 44129-44137.

[20] Contarini, G., Povolo, M., Pelizzola, V., Monti, L., Bruni, A., Passolungo, L. et. al. (2014). Bovine colostrum: Changes in lipid constituents in the first 5 days after parturition. Journal of Dairy Science, 97 (8), 5065-5072. doi: https://doi.org/10.3168/ jds.2013-7517

[21] Coroian, A., Erler, S., Matea, C. T., Mireșan, V., Răducu, C., Bele, C., Coroian, C. O. (2013). Seasonal changes of buffalo colostrum: physicochemical parameters, fatty acids and cholesterol variation. Chemistry Central Journal, 7 (1). doi: https://doi.org/ $10.1186 / 1752-153 x-7-40$

How to cite: Ivanov, I., Kozheshkurt, V., Bozhkov, A., Goltvjansky, A., Katrich, V., Sidorov, V., Gromovoy, T. (2021). Low-molecular components of colostrum as a regulator of the organism redox-system and biological antidote. EUREKA: Life Sciences, 2, $56-64$. doi: https://doi.org/10.21303/2504-5695.2021.001738 